\title{
The Phenomenological Study of Patients' Family Experience in Early Detecting of Sign and Stroke Sympthom Pre-Hospital in Regional Public Hospital of Pariaman
}

\author{
Mike Asmaria $^{1 *}$ and Vivi Yuderna ${ }^{2}$ \\ ${ }^{1,2}$ Dep. of Health and Recreation, Faculty of Sports Sciences, Universitas Negeri Padang, Padang, Indonesia \\ *Corresponding author. Email: mikeasmaria@fik.unp.ac.id
}

\begin{abstract}
WHO (2016) states that stroke is one of the causes of 6.7 billion deaths per year around the world. The slow identification of stroke symptoms causes handling delays and extends the damage of neurology. The purpose of this research is to identify the experience of the patient's family in early detecting the sign and symptoms of pre-hospital stroke. The design of the research is qualitative research with the phenomenology mode Colaizzi approach. The data has been collected through in-depth interviews and field notes. The participants consist of seven families of patients with non-hemorrhagic stroke. The results of the research have found 3 themes, as follows: (1) Observing the physical changes of the patient, (2) giving traditional medicine (3) Bringing patients to a health officers. The result of the research is expected the hospital can do cooperation with medical service reconciliation to educate early detection of stroke pre-hospital especially to the patient who is at risk of stroke factor.
\end{abstract}

Keywords: stroke, pre-hospital, early detection

\section{INTRODUCTION}

According to WHO, stroke is a nervous system function deficit symptom that is caused by vascular disease[1]. WHO (2016) states that stroke is the cause of 6.7 million deaths every year worldwide, and causes 6 deaths every 60 seconds. The increasing of stroke occurs 30 incidents worldwide. Based on Rikesdas data on 2018, the prevalence of stroke has reached 10.9 per mil. The prevalence level of stroke in West Sumatra Province is the highest that isalmost equal to 10.9 per mil. Stroke patients who treat on RSUD Pariaman increases, 162 cases in 2017 and 193 cases in 2018.

According to the height of stroke prevalence is caused by unresponsive behavior or underestimating early signs of stroke (62.3\%) [2]. The slow of sign recognition of stroke willproduce delays in handling. Research conducted by Pinzon in Yogyakarta $87 \%$ of patients came more than 3 hours after the attack and $46 \%$ of them came $>24$ hours after the attack.

Furthermore, early sign recognition is needed to get appropriate handling or treatment. A research state that the signs and symptoms of stroke using the CPSS ( Cincinati Prehospital Stroke Scale ) showed a good sensitivity of $81 \%$ [3]. CPPS or FAST will accelerate the early handling and reduce neurological damage of patients. Pariaman District Hospital, it was found that two of three families of patients did not know about the exact signs of stroke symptoms. The families of stroke patients have not been able to make early detection of appropriate signs of stroke. It influences decision making of family in early handling of patients who tend not to carry the patients to the hospital immediately.

Based on the background above, the researcher is interested in doing research on the patients' family experience In Early Detection Signs and Symptoms of Stroke Pre-Hospital in Pariaman Public Hospital.

\section{RESEARCH METHOD}

The method of this research is qualitative research with phenomenological approach, and the data analysis was using Colaizzitechnique. The population of this research was the families of stroke patients who were being treated and treated in the neurology department of Pariaman Public Hospital. The numbers of participants in this research were 7 participants. The Participants were the families of stroke patients who are being treated and treated in Pariaman Public Hospital, which were as new patients with criteria of having a non-hemorrhagic stroke, when the research was conducting, the participants werethe families who accompanied the 
patients in daily, involved in taking patients to the hospital, and willing to be informants in this research.

\section{RESEARCH RESULT}

The results of the research were obtained in three themes, as follows: 1) Observing the physical changes of the patient, 2) gave traditional medicine, 3) Taking the patients to health employee

\section{Observing the physical changes of the patient}

In this research, the participants conducted early detection of stroke symptoms by observing the patient's mouth chewing, observing the presence of complaints of speech / pelo, observing the weakness of the patien limb.

a. Observing the patient's mouth

The results of interview with some participants revealed that the families saw physical changes of patient's mouth, the expression of participants as follows: "muncuangyo kencong..di cubo apo kan,, minum e,,dak taminum die..kalua aie lah maleleh (Pl) (His mouth is wringing, what are you trying to do ... drink, it can't be drunk by him ... the water has melted out) "It looks like the bibie is a bit thick, cuttings." (P2) (The lips look a little bit bowed) "Muluiknyo, sis. If you say hello to sue aia liua kalua ajo..did not be able to build. "(P4) (His mouth, sis, in the right side his spit water out of the spit, he can't chew) "muncuage ko lah kencong sakali.."(P7) (His mouth has started aslant).

b. Observing complaints of speech (pelo)

Most participants revealed that there was a change in patient communication, patients could not speak clearly. The following is participant expressions:

"ma pengen urut? Aaa..wlwlwlwl sudah patah lidahnyo . " (Pl) (I want to massage? Aaa. Wwwwwww..her tounge has broken) "kalau wak tanyo nan ma sakik lok?.. kecek e..muncuang e kencong tu dak jaleh kecek." (P2) (when we asked which one is sick Lok? .. her mouth is aslant..then her speaking is not clear) " ngomongnya..udah mulai nggakjelas"(P5)

"Tu agiahan telfon ka nyo.. tu lidahnyo uluhh uluuhh keceknyo tu"(tu" (P6)

(Then it was given telephoned to him ... then his tongue, uluhhh uluhhh"he said"

"Langsuang dak bisa ngecek apak ko " (P7)

(That man can't speak anymore)

\section{c. Observing the weak of limbs}

Based on the result of the research was obtained the participants expression that when a patient had stroke attack, the symptoms of limb weakness were found.

"tu cubo e gerak badan tangan kan..dak kuaik gerak e do..barek sabalah suok.. ndak bisa digarikkan doh" (P1) (then trying to move his body of right hand, it can't move well, the right hand is weight, and can't be moved) "Cubo angkek tangan lok kecek wak.." dak amuah doh kcek e,,lamah tangan den,,"kecek e,,saketek taangkek, lamah sabalah kiri atau kida" ( (P2)

(Try to raise your hand Lok, I said ... it can't, she said ... my hand is weak, she said ... just raise a little bit ,, weak on the left hand )

" lamah..tu lah makanyo sadonyo dak batanango. tagak pun susah"(P3)

(weak.. that's why anyting is not has power, even hard to stand)

"Lamahhhhhh ajo Tangannyoooo sabaalah suok"(P4)

(her right hand is weak ... )

" mulailah tanganya gak bisa di gerakkan,,dia gak bisa jalan" ( P5)

" tangan maraba-raba, tangan dan kaki sabalah kanan dan dak bisa di gerak an.." (P7)

(groping hands, right hand and foot cannot be moved)

\section{Giving traditional medicine}

Based on the results of interview with the participants were found that after patients diagnosed getting stroke, the family tend to give traditional medicine first, which of chase scan patient's mouth twisted disclosed said two participants, by massaging/ massaging by a masseuse/shaman expressed by four participants. Below is the participants expression:

" Langsuang ita tampa pipi e, yo nyo lah mangencong,, kecek urang lo kan supayoluruiih kecek e." (P 1)

(Ita slapped his cheek immediately, yes he has already gawked .. people also said to make it straight, she said)

" uni ambiak je minyak GPU kan,, muncuang ko lah gho.. ghoohoo,, kecek e kan,,aa tu ni apoaan,,uni agiah minyak GPU tu a,," (P 7 ) (uni took GPU oil ,, it was ghoghoohoo his mouth, right. Then, uni gives GPU oil)

"...bawo ka tampek tukang uruik. sudah tu siap baruik tu kan balik pulang..." (P1) .

(taking him to the masseuse, after that back to home ) "Bauruik ajo, sih, samo tukang uruik ..." (P4)

(Just massage with the massaseuse)

"...tu bawo urang pandai apo tadi kan kalau dikampuang kan bauruik dulu dikompres aiaangek samo garam sampai lihia sampai muko tu ditarik lidahnyo.." (P 6 )

(Then, taking to shaman ... in the village take to massage first, compress with warm water and salt to the neck and face, then pull the tongue).

" ugku tu yang uruik-uruik pinggang e, kaki e,,tangan e,, a tu pelokkan muncuag e sketek lai,,," (P7)

(That shaman massages his waist, legs, hands, then fixing his mouth a little). 


\section{Bringing Patients to Health Officers}

The results of interviews with participants revealed that family behavior when seeking help after a patient was detected stroke by a family, the family brought the patient to the health worker either after getting traditional treatment or first reconciliation. The following are the health workers encountered by the family before being taken to the hospital: Midwives, 4 participants were told thattake the patient to the midwife, one participant said that there are nurses who gave treatment to patients in the clinic, one participant said that the doctor as a helper when the patient had a stroke, These are the following participant expression:

" Peklah Barubek Kito Ka Bidan Desa...baantaan ka bidan " (P 3 )

(Let wego to treat to the midwife ... taking to the midwife)

" Baok ka puskesmas.tu tunggu dokter, dokter alun tibo, tu nyo agiah ubek dek bidan.." (P1).

(take him to the puskesmas, waiting for doctor, the doctor hasn't arrived yet, then given medicine by the midwife)

" bidan desa telfon bidan desa tu .ooo." (P6).

\section{RESULT AND DISCUSSION}

1. Theme 1: Observing the physical changes ...... of the patient

In doing early detection, National Stroke Association (NSA) there are some measurement stages such as asking the patient to smile, raising both arms and notice to the arms which fall first, and repeating simple words [4]. Research revealed that introduction of lamentation and symptoms of stroke for patients and their family are really needed [5].

Based on the results of this research, the family has not done the FAST steps consisting of facial movement, arm movement, and speech correctly. Families still have seen or observed after patients had gotten physical changes or worse neurological damage. Moreover, there werestill families who had not found signs of stroke symptoms of the patients before took to the hospital. Based onseven participants, two of them considered the patients' disease were not a stroke. From the demographic data of participants, most of the familiesstate that therehas never gottenknowledge about stroke directly. In a line with which state that there is a relationship between knowledge with early stroke detection ability [6].

In accordance with a research which indicate the respondents' knowledge of stroke are still low, that is $63 \%$ of 174 [7].The respondents answered the signs of stroke symptoms are the difficulties in speaking, weakness in the limbs. But, the respondents cannot mention the symptoms of stroke anymore. Less of knowledge influences the process of identifying the signs of stroke symptoms.

In this research, the ability of families in identifying signs of stroke symptoms was revealed by participants by observing the patient's mouth chewing, observing the presence of speech complaint (pelo), observing weaknesses in the patients' limbs. This is different from a research where participants have observed speech difficulties $(65 \%)$, have asked for numbness and paralysis (63\%), but participants have not observed the presence of a choked face (58\%) [8].

The difference of the research above is caused by the lack of family knowledge in doing early detection of signs the stroke symptoms. In addition, it is caused by the lack of knowledge about how to do early detection of signs the stroke symptoms correctly. For this reason, it is necessary to socialize or disseminate knowledge about steps in conducting early detection of signs and symptoms of stroke pre-hospital from health workers directly to public, especially to the patients and their families who are at risk of stroke such as hypertension, diabetes, heart disease, smoking, cholesterol, overweight, lack of exercise and stress.

\section{Theme 2: Giving traditional medicine}

The three complete phases of stroke management are the pre-hospital phase, the hospital phase and poststroke phase. The pre-hospital phase is the phase where the patient has to get emergency treatment. According to the ideal facilities of emergency department is the trained workers (doctors, nurses , and the driver of the ambulance), ECG machines, equipment and neuroprotective medicines, telemedicine, checking blood sugar levels, levels of $\mathrm{O} 2$ saturation, and have to be able to provide the transportation fast.

In this research, most of families have found the signs of stroke symptoms, but the families tended to take the patients to non-health care workers or traditional treatment. Patients got traditional treatments such as massage by non-health care workers and masseurs.

The results of this study are the same as which states one of the behaviors of patients when suffering from stroke is to the hospital after being taken to traditional medicine [9]. This is probably caused by several factors that influence health behavior, namely education, culture, geography and demographics.

According to Setyoningsih states that the reason of chosen a healing method is based on belief, the severity of illness, and the cause of the disease [10]. The Factors that encourage a person to determine the treatment method is based on internal and external factors. Internal factors come from oneself who wants healing, while external factors come from experience 
of people or communities who have suffered from the same disease, and which healing has healed them. The first treatment before choosing between traditional or medical healing is self-medication. After the disease gets worse, then look for other healing treatment, such as going to alternative medicine, or going to medical treatment.

Cultural elements of taking the patients to nonhealth workers such as traditional medicine are more dominant to be the first helper for patients, before going to health services. Even though the participants are in high school education level and even in bachelor degree level, but they still did not quite understand of early treatment for patients because they never had obtained the knowledge from health workers. In a line with states that there is a significant relationship between family knowledge about stroke and pre - hospital treatment.

For this reason, the role of health workers is needed to deliver the knowledge about stroke and early treatment of stroke attack. Health workers have tofasten the process of patient reconciliation to the hospital, the needsof knowledge about appropriate emergency care facilities for patients.

\section{Theme 3: Bringing Patients to Health Officers}

In this research, most of families take stroke patients to health workers such as midwives, doctors that is available in the area of the patient lives. More than one third of stroke cases are checked by health workers first before being taken to the hospital to confirm the patient's illness.

The results of this research are different from the research which shows that $77 \%$ of respondents feel stroke as an emergency condition and will take the patients to the hospital immediately [11]. Doctors, nurses and midwives as health workers are expected to be the actors ofcues to action to change health seeking behavior.

The success of stroke management is started from the public knowledge and health workers that stroke is an emergency condition "Time is Brain". Recognizing Transient ischemic attack (TIA) and common understanding will be very instrumental in saving and preventing long-term disability due to stroke [12].

The Professional health workers have knowledge of stroke complaints, especially in the high risk stroke community. Pre-hospital management responsibilities depend on ambulance services and primary health care.

Health workers who get the patients with the signs of symptoms stroke have to determine the priority or the level of emergency of the patient by doing assessment, one of them is FAST method.

In this research, most of participants revealed the health workers have given blood pressure measurement, medicine for decreasing blood pressure, as well as recommendation to take the patient to the hospital. While, the process of sending patients have not been done in accordance with emergency procedures for stroke, such as guiding the reconciliation for patients to the hospital, and using ambulances as the emergency transportation.

This is probably because the patients had come after received other treatment before being taken to a health worker. Health workers that have been met is a basic service that has not had facilities of pre hospital phasethat in accordance with the protocol stroke management. Furthermore, the patients who come are not able to be helped and have to be reconciled.

Other factors that influence the process of health workers service is the lack of health workers' knowledge about treatment of stroke pre- hospitaland inadequate emergency facilities for early stroke attack patients. This is in a line with a research who conducted a pre-test of nurses' knowledge about early detection. It was found that nurses' knowledge with less categories are about 29 respondents and good categories about 3 respondents.

For this reason, it is necessary to refresh knowledge about early detection the signs of stroke symptoms, especially the FAST method, those are fascial droop (weakness of one side of face), arm drift (weakness of one arm), and speech (pelo's speech, have difficulties or unable to speak, words issued incorrectly), Time (contact the emergency services center for transportation to health facilities immediately). Beside refreshing knowledge through seminars or training, the need for adequate facilities from the health department either in terms of Human Resources or emergency equipment that is suitable with stroke management protocols.

\section{CONCLUSION}

The results of the research based on data that has been gotten is most of participants have not known how to detect the early signs and symptoms of stroke properly. The inappropriate method of early detection can cause delays in recognizing the patient's illness, which will be worsening the patient's condition.

Based on the result, hospitals and referring health services can provide knowledge about early recognition ofthe signs and symptoms of stroke forpublic, especially for patients who have stroke risk factors. Expecting to Health department can provide either adequate facilities in terms of Human Resources or stroke emergency 
equipment that is suitable to the stroke management protocols, refreshing knowledge through seminars or training about recognizing the early detection of stroke by the education side.

Based on data analysis and discussion that has been presented previously, it can be concluded that aerobic exercise that is carried out regularly can improve student physical fitness. We recommend a program of aerobic exercise with 24 meetings with 3-times-a-week exercise for 8 weeks, and the training load of $60-85 \%$ of the maximum pulse.

\section{REFERENCES}

[1] World Health Organization.(2011). The Top 10 Causes of Death in The World, http://who.int/ mediacentre/factsheets/fs310/en/

[2] Cook, LK., Clement, SL. (2011). Stroke Recognition and Management; Early Identification and Treatment are the keys. AJN;111(5).

[3] Maddali, Aditya. (2018). Validation of the cincinnati prehospital stroke scale; Journal of Emergencies, New Delhi Vol. 11, Iss. 2

[4] Pinzon, R. \& Asanti, L. (2010).Awas Stroke!!Pengertian, Gejala, Tindakan, Perawatan, danPencegahan. Yogyakarta: C. Andi Oset.

[5] Maddali, Aditya. (2018). Validation of the cincinnati prehospital stroke scale; Journal of Emergencies, New Delhi Vol. 11, Iss. 2
[6] Sari, L., Yuliano, A, \& Almudriki, A.(2019). Hubungan Pengetahuan dan Sikap Keluarga terhadap Kemampuan Deteksi Dini Serangan Stroke Iskemik Akut pada Penanganan Pre Hospital. Perintis's Health Journal. Vol 6 No 1

[7] Sari, L., Yuliano, A, \& Almudriki, A.(2019). Hubungan Pengetahuan dan Sikap Keluarga terhadap Kemampuan Deteksi Dini Serangan Stroke Iskemik Akut pada Penanganan Pre Hospital. Perintis's Health Journal. Vol 6 No 1

[8] Setianingsih, (2019). Studi Deskriptif Penanganan Prehospita Stroke Life Support pada keluarga. Jurnal Perawat Indonesia, Volume 3 No 1, Hal 5564, Mei 2019. E-ISSN 2548

[9] Hariyanti, T. Harsono. Prabandari. Y (2015). Health Seeking Beavior on Stroke Patients. Jurnal Brawijaya, Vol.28, no.3

[10] Setyoningsih, A \& Myrtati D. Artaria (2016). Pemilihan penyembuhan penyakit melalui pengobatan tradisional non medis atau medis. Masyarakat, Kebudayaan dan Politik Vol. 29, No. 1, hal. 44-56

[11]Na'im, A.,Arisdiani, T,.Hermanto, (2019). Hubungan Tingkat Pengetahuan Keluarga Tentang Penyakit Stroke dengan Penanganan Pre-Hospital. Jurnal Gawat Darurat. Volume 1 No 1 Hal 13-24

[12] Berry, JD., et al, 2013. Heart Disesase and Stroke Statistics. A.Report from the American Heart Association. Circulation; 127 